\title{
RETROSPECTIVE EVALUATION OF THE EFFECT OF AMMONIA LEVELS ON MORTALITY IN PATIENTS WITH HEPATIC ENCEPHALOPATHY APPLYING TO THE EMERGENCY DEPARTMENT
}

\author{
Acil Servise Başvuran Hepatik Ensefalopatili Hastaların Amonyak Düzeylerinin Mortaliteye \\ Etkisinin Retrospektif Değerlendirilmesi
}

İremgül GÜNGÖR ${ }^{1}$ (D), Ahmet Burak ERDEM²

\author{
${ }^{I}$ Samsun Training and Research Hospital, Emergency Medicine Deparment, SAMSUN, TÜRKIYE \\ ${ }^{2}$ Ministry of Health Ankara City Hospital, Emergency Medicine Department, ANKARA, TÜRKIYE
}

Objective: Hepatic encephalopathy is a cognitive, motor and behavioral disorder caused by the accumulation of liver metabolism products accompanying hepatic failure. The clinical picture of hepatic encephalopathy appears with the accumulation of metabolites such as ammonia and gamma aminobutyric acid. In our study, we aimed to investigate the effect of blood ammonia levels on mortality in patients diagnosed with hepatic encephalopathy.

Material and Methods: The records of patients who were admitted to the emergency department of our hospital with impaired consciousness, known chronic liver disease, and whose ammonia levels were studied between January 012015 and December 312018 were retrospectively analyzed. Liver function tests and coagulation tests of the patients were recorded. The patients were divided into two groups as with and without hepatic encephalopathy. The groups were divided into stages according to the West Haven classification. Liver function tests and coagulation tests of the two groups were compared according to ammonia level, disease stage and mortality.

Results: Four hundred and thirty-five of 883 patients whose ammonia levels were studied between 2015-2018 were included in the study. The age of the patients included in the study ranged from 18 to 95 years. One hundred and forty -four of them were female. When the relation of ammonia value with mortality was examined, there was no statistically significant difference $(\mathrm{p}=0.620)$. There was a statistically significant increase in the liver function test values and coagulation test values in the patients with hepatic encephalopathy who died.

Conclusion: While there is no correlation between ammonia level and mortality in hepatic encephalopathy patients, it is important in terms of mortality in chronic liver diseases.
Amaç: Hepatik ensefalopati, hepatik yetmezliğe eşlik eden karaciğer metabolizma ürünlerinin birikimi sonucu meydana gelen bilişsel, motor ve davranışsal bozukluktur. Hepatik ensefalopati klinik tablosu, amonyak ve gama aminobütirik asit gibi metabolitlerin birikimi ile karşımıza çıkmaktadır. Çalışmamızda hepatik ensefalopati tanısı konulan hastaların kan amonyak düzeyleri incelenerek mortalite üzerine etkisinin araştırılması amaçlanmıştır.

Gereç ve Yöntemler: Çalışmaya, hastanemiz acil servisine 01.01.2015-31.12.2018 tarihleri arasında bilinç bozukluğu ile başvuran, bilinen kronik karaciğer hastalığı olan, amonyak düzeyi bakılan hastaların kayıtları dahil edilmiştir. Hastaların karaciğer fonksiyon testleri ve koagülasyon testleri kaydedildi. Hastalar, hepatik ensefalopati olan ve olmayan olarak iki gruba ayrıldı. Gruplar, West Haven sinıflamasina göre evrelere ayrıld. İki grubun karaciğer fonksiyon testleri ve koagülasyon testleri amonyak seviyesi, hastalı evresi ve mortaliteye göre karşılaştırıldı.

Bulgular: Acil servisimize 2015-2018 y1lları arasında gelen ve amonyak düzeyi çalışılan 883 hastanın 435 tanesi çalışmaya dahil edilmiştir. Çalışmaya dahil edilen hastaların yaşı, 18-95 arasında dağılım göstermektedir. Hastaların 144'ü kadındı. Amonyak değerinin mortalite ile ilişkisine bakıldığında istatistiksel olarak bir fark yoktu $(p=0,620)$. Karaciğer fonksiyon testlerinde ve koagülasyon testlerinde hepatik ensefalopatisi olan hastalardan ölenlerin değerlerinde istatistiksel olarak anlamlı bir yükselme vardı.

Sonuç: Hepatik ensefalopati hastalarında amonyak düzeyi ve mortalite arasında bir korelasyon yok iken kronik karaciğer hastalarında mortalite açısından önemlidir.

Anahtar Kelimeler: Amonyak, hepatik ensefalopati, mortalite 


\section{INTRODUCTION}

Hepatic encephalopathy (HE) is a neuropsychiatric abnormality seen in patients with hepatic dysfunction without other underlying neurological and metabolic disorders (1). It is a clinical syndrome involving cognitive, motor and behavioral disorders that occur as a result of the accumulation of liver metabolism products accompanying hepatic failure. The liver has functions such as synthesis, storage, digestion, and toxic substance elimination. Some metabolites accumulate in the body as a result of a defect in toxic substance elimination. Hepatic encephalopathy clinical picture appears with the accumulation of metabolites such as ammonia and gamma aminobutyric acid (2). HE refers to the brain dysfunction that develops due to metabolites and metabolic abnormalities that are released and cannot be eliminated by the liver. While icterus, ascites, edema, fetor hepaticus are seen in acute insufficiency clinically; muscle weakness, spider telangiectasias and palmar erythema are seen in long-term hepatic dysfunction. Diurnal sleep rhythm disturbance (insomnia and hypersomnia) is common in patients with $\mathrm{HE}$ and typically leads to neurological symptoms. There are more advanced neurological manifestations such as bradykinesia, asterixis, hyperactivity in deep tendon reflexes and rarely, transient decerebral posture and hemiplegia (3). When laboratory parameters are examined, increased liver enzyme values, increased bilirubin levels, hyperammonemia, decreased Factor 27-9-10 levels, prolonged prothrombin time due to Protein C/S deficiency/Activated partial thromboplastin time/International correction ratio (PT/aPTT/INR) disorder are frequently seen. This is due to the impairment of the synthesis, conjugation and secretory functions of the liver. Necrosis that occurs in hepatocytes leads to impaired liver function (4). In addition, ammonia is the best defined neurotoxin precipitating HE (5). Developing portal hypertension, splenomegaly, and folic acid deficiency are effective in the development of thrombocytopenia in patients with chronic liver disease (6).

In this retrospective study, we aimed to show the effect of ammonia level on mortality in patients with hepatic encephalopathy. In addition, we analyzed the clinical stage, hemostasis values, liver function tests and platelet values of hepatic encephalopathy patients.

\section{MATERIALS AND METHODS}

Since our study was conducted retrospectively on biochemical blood parameters and did not contain data such as identity information, biometric images and pictures of the patients that would reveal patient information, patient consent was not obtained. The study was conducted in accordance with the Declaration of Helsinki Principles. Approval was obtained from the local ethics committee (Ankara Numune Training and Research Hospital Clinical Research Ethics Committee, date: 28.09.2019, issue number: E-19-2644).

In our study, medical records of 883 patients who applied to a Training and Research Hospital Emergency Service between January 012015 and December 31 2018 and whose blood ammonia levels were studied were retrospectively evaluated. Patients admitted to the emergency department of our hospital with impaired consciousness, history of known chronic liver disease, and whose blood ammonia level was studied were included in the study. From the records obtained, patients who were pregnant, who were under 18 years of age, who were using antiplatelet and anticoagulant drugs, patients with drug intoxications, and patients without measured ammonia value were not included in the study. A total of 435 patients were included in the study.

The study we conducted was a controlled, retrospective, observational study. A study form was used in our study. In the study form, in addition to demographic data such as age and gender evaluated for each patient participating in the study, platelet (PLT) count, alanine 
aminotransferase (ALT), aspartate aminotransferase (AST), alkaline phosphatase (ALP) and gamma glutamyl transferase (GGT), total bilirubin (T.BIL), direct bilirubin (D.BIL), hemostasis tests (PT: 10-14 seconds, aPTT: 23-35 seconds, INR: 0.8-1.2 reference value), blood ammonia level, hepatic encephalopathy stage, presence of known chronic of liver disease, etiologic causes of hepatic encephalopathy, and mortality were evaluated. Patients were divided into 2 groups as HE and non-HE patients. The relationship between hemogram and biochemical parameters between the living and the dead was examined. Finally, in all patient groups the relation of ammonia level with mortality was examined.

HE was graded 1-4 according to the severity of signs and symptoms according to the West Haven criteria. In Stage 1 insomnia, hypersomnia, computational difficulty, euphoria and tremor are present. In Stage 2 lethargy, decreased attention, time disorientation, talkativeness, aggression, manuscript impairment, aggravation of speech, and asterixis may occur. In Stage 3 sommolence, confusional state are present. Anxiety, meaningless behavior, nystagmus, ataxia, and hypo / hyper activity in reflexes can be seen. Location orientation deteriorates and the patient cannot calculate. In Stage 4 stupor, coma, complete loss of skills, paranoia, anger, babinski sign, mydriasis, opistotonus, and muscle rigidity may develop (7).

Veonus blood samples were taken from the patients. Ammonia level was measured by enzymatic method on Cobas 6000 analyzer (Roche Diagnostics International Ltd CH-6343 Rotkreuz Switzerland). The reference range was $68-136 \mathrm{mg} / \mathrm{dL}$.

\section{Statistical Analysis}

The research data was uploaded to the computer using the SPSS 20 (Statistical Package for Social Sciences) program and evaluated. Descriptive statistics are presented as mean \pm standard deviation $( \pm \mathrm{SD})$ and percentage. In paired group comparisons, "Student's $t$
Test" was used when parametric assumptions were provided, and in cases where parametric assumptions were not met, "Mann-Whitney U Test" was used as statistical method. Pearson's correlation test was used to show the effect of ammonia test on mortality. Logistic regression analysis was performed to show the strength of the relationship. Statistical significance level was accepted as " $p<0.05 "$.

\section{RESULTS}

The ages of 435 patients included in the study ranged from 18 to 95 years. The average age of patients with HE was 62.52, and for those without HE, the mean age was 62.72. Of the patients, 291 were male. While $52.6 \%$ of the patients $(n=229)$ had HE, 47.4\% $(n=206)$ did not have HE. Gender, HE stage and mortality distribution of patients with HE are summarized in Table 1.

Table 1: Age, stage and mortality distribution of patients with hepatic encephalopathy

\begin{tabular}{llcl}
\hline Variable & & $\mathbf{n}$ & $\mathbf{\%}$ \\
\hline Gender & Male & 152 & 66.4 \\
\cline { 2 - 4 } & Female & 77 & 33.6 \\
\hline Stage & 1 & 82 & 35.8 \\
\cline { 2 - 4 } & 2 & 72 & 31.4 \\
\cline { 2 - 4 } & 3 & 30 & 13.1 \\
\hline Mortality & Alive & 45 & 19.7 \\
\cline { 2 - 4 } & Dead & 58 & 74.7 \\
\hline
\end{tabular}

When the predisposing factors causing $\mathrm{HE}$ were examined in our study; infections were the most common precipitating factor with a rate of $53.27 \%$ $(n=122)$. Urinary tract infection was found to be the most common infective cause of $\operatorname{HE}(39.34 \%, n=48)$. The second most common cause was renal failure $(n=31)$. Acute gastroenteritis $(n=26)$, pneumonia $(n=25)$ and peritonitis $(n=23)$ were other detected infective causes. 
The relationship between mortality and liver enzymes, bilirubin level, coagulation tests and ammonia in patients with HE is summarized in Table 2. There was no statistically significant relationship between ammonia and mortality $(\mathrm{p}=0.620)$. In the logistic regression analysis, we found that it was very low with $\mathrm{R}=0.102$ and $\mathrm{p}=0.123$. No relationship could be established between ammonia and mortality.

Table 2: Distribution of age, gender, liver enzymes, bilirubin, ammonia, coagulation and platelet values in patients with hepatic encephalopathy

\begin{tabular}{|c|c|c|c|c|c|}
\hline Variable & & $\mathbf{n}$ & SD & Mean & $\mathbf{p}$ \\
\hline \multirow[t]{2}{*}{ Age } & Alive & 171 & 13.52 & 62.78 & \multirow{2}{*}{0.544} \\
\hline & Dead & 58 & 13.19 & 61.76 & \\
\hline \multirow[t]{2}{*}{ Gender } & Alive & 171 & 0.47 & 1.34 & \multirow{2}{*}{0.873} \\
\hline & Dead & 58 & 0.47 & 1.33 & \\
\hline \multirow[t]{2}{*}{ ALT } & Alive & 171 & 257.93 & 66.44 & \multirow{2}{*}{0.002} \\
\hline & Dead & 58 & 569.11 & 217.93 & \\
\hline \multirow[t]{2}{*}{ AST } & Alive & 171 & 453.54 & 115.37 & \multirow{2}{*}{$<0.001$} \\
\hline & Dead & 56 & 1147.03 & 443.05 & \\
\hline \multirow[t]{2}{*}{ GGT } & Alive & 171 & 240.99 & 128.07 & \multirow{2}{*}{0.013} \\
\hline & Dead & 58 & 521.01 & 277.97 & \\
\hline \multirow[t]{2}{*}{ ALP } & Alive & 160 & 106.29 & 151.78 & \multirow{2}{*}{0.011} \\
\hline & Dead & 57 & 286.92 & 244.61 & \\
\hline \multirow[t]{2}{*}{ Direct Bilirubin } & Alive & 171 & 4.23 & 1.70 & \multirow{2}{*}{$<0.001$} \\
\hline & Dead & 57 & 6.45 & 5.02 & \\
\hline \multirow[t]{2}{*}{ Total Bilirubin } & Alive & 162 & 3.17 & 2.85 & \multirow{2}{*}{$<0.001$} \\
\hline & Dead & 56 & 8.83 & 7.71 & \\
\hline \multirow[t]{2}{*}{ Ammonia } & Alive & 171 & 134.37 & 233.66 & \multirow{2}{*}{0.620} \\
\hline & Dead & 58 & 199.57 & 269.71 & \\
\hline \multirow[t]{2}{*}{ aPTT } & Alive & 164 & 6.37 & 33.85 & \multirow{2}{*}{0.030} \\
\hline & Dead & 58 & 15.84 & 38.57 & \\
\hline \multirow[t]{2}{*}{ PT } & Alive & 167 & 7.94 & 18.45 & \multirow{2}{*}{$<0.001$} \\
\hline & Dead & 58 & 26.70 & 25.84 & \\
\hline \multirow[t]{2}{*}{ INR } & Alive & 167 & 0.74 & 1.64 & \multirow{2}{*}{$<0.001$} \\
\hline & Dead & 58 & 2.83 & 2.36 & \\
\hline \multirow[t]{2}{*}{ Platelet } & Alive & 171 & 63.22 & 122.01 & \multirow{2}{*}{0.006} \\
\hline & Dead & 58 & 88.96 & 157.03 & \\
\hline
\end{tabular}

SD: standard deviation; p: Mann-Whitney U Test;

(ALT: Alanine aminotransferase, AST: Aspartate aminotransferase, ALP: Alkaline phosphatase, GGT: Gamma glutamyl transferase, aPTT: Activated partial thromboplastin time, PT: Prothrombin time, INR: International correction rate) 
Table 3. Age, Hepatic Encephalopathy Stage and Mortality Distribution of All Patients

\begin{tabular}{llcc}
\hline Variable & & n & \% \\
\hline Gender & Male & 289 & 66.4 \\
& Female & 146 & 33.6 \\
\hline Stage & Hepatic Encephalopathy None & 206 & 47.4 \\
& 1 & 82 & 18.9 \\
& 2 & 72 & 16.6 \\
& 3 & 30 & 6.9 \\
\hline \multirow{2}{*}{ Mortality } & Alive & 45 & 10.3 \\
& Dead & 335 & 77 \\
\hline
\end{tabular}

Table 4: Distribution of age, gender, liver enzymes, bilirubin, ammonia, coagulation and platelet values of all patients

\begin{tabular}{|c|c|c|c|c|c|}
\hline Variable & & $\mathrm{n}$ & SD & Mean & $\mathbf{p}$ \\
\hline \multirow[t]{2}{*}{ Age } & Alive & 335 & 14.95 & 62.51 & \multirow{2}{*}{0.391} \\
\hline & Dead & 100 & 15.40 & 62.96 & \\
\hline \multirow[t]{2}{*}{ Gender } & Alive & 335 & 0.47 & 1.35 & \multirow{2}{*}{0.886} \\
\hline & Dead & 100 & 0.46 & 1.30 & \\
\hline \multirow[t]{2}{*}{$\mathrm{ALT}$} & Alive & 333 & 355.67 & 109.27 & \multirow{2}{*}{$<0.001$} \\
\hline & Dead & 100 & 470.43 & 196.26 & \\
\hline \multirow[t]{2}{*}{ AST } & Alive & 333 & 464.94 & 155.15 & \multirow{2}{*}{$<0.001$} \\
\hline & Dead & 98 & 981.41 & 417.47 & \\
\hline \multirow[t]{2}{*}{ GGT } & Alive & 334 & 395.75 & 177.38 & \multirow{2}{*}{0.024} \\
\hline & Dead & 100 & 509.63 & 272.48 & \\
\hline \multirow[t]{2}{*}{ ALP } & Alive & 309 & 158.05 & 175.64 & \multirow{2}{*}{0.002} \\
\hline & Dead & 99 & 410.23 & 306.19 & \\
\hline \multirow[t]{2}{*}{ Direct Bilirubin } & Alive & 335 & 3.84 & 1.98 & \multirow{2}{*}{$<0.001$} \\
\hline & Dead & 98 & 6.46 & 5.05 & \\
\hline \multirow[t]{2}{*}{ Total Bilirubin } & Alive & 318 & 3.94 & 3.22 & \multirow{2}{*}{$<0.001$} \\
\hline & Dead & 94 & 9.88 & 7.95 & \\
\hline \multirow[t]{2}{*}{ Ammonia } & Alive & 335 & 131.35 & 157.96 & \multirow{2}{*}{0.093} \\
\hline & Dead & 100 & 183.73 & 194.60 & \\
\hline \multirow[t]{2}{*}{ aPTT } & Alive & 320 & 9.56 & 33.83 & \multirow{2}{*}{0.003} \\
\hline & Dead & 100 & 16.94 & 39.09 & \\
\hline \multirow[t]{2}{*}{ PTZ } & Alive & 324 & 10.19 & 18.71 & \multirow{2}{*}{$<0.001$} \\
\hline & Dead & 100 & 24.26 & 26.84 & \\
\hline \multirow[t]{2}{*}{ INR } & Alive & 324 & 1.23 & 1.67 & \multirow{2}{*}{$<0.001$} \\
\hline & Dead & 100 & 2.66 & 2.49 & \\
\hline \multirow[t]{2}{*}{ Platelet } & Alive & 335 & 94.43 & 159.72 & \multirow{2}{*}{0.955} \\
\hline & Dead & 99 & 132.71 & 166.28 & \\
\hline
\end{tabular}

SD: standard deviation; p: Mann Whitney U Test;

(ALT: Alanine aminotransferase, AST: Aspartate aminotransferase, ALP: Alkaline phosphatase, GGT: Gamma glutamyl transferase, aPTT: Activated partial thromboplastin time, PT: Prothrombin time, INR: International correction rate)

Age, HE stage and mortality status of all patients are summarized in Table 3. In the group with HE, the mean value of ammonia was 242.79 , while its standard deviation was 153.84. In the non-HE group, the mean value of ammonia was 81.07, while its standard deviation was 68.79. There was a statistically significant difference between patients with and without $\mathrm{HE}$ $(p<0.001)$. The relationship between age, gender, liver 
function tests, coagulation tests and platelet values of alive and deceased patients in all patients are summarized in Table 4. Considering the relationship between mortality and ammonia among all patients, it was found that $\mathrm{R}=0.106$ and $\mathrm{p}=0.027$ in linear regression analysis and $\mathrm{p}=0.030$ in binomial logistic regression analysis. There was a statistically significant relationship between ammonia and mortality in all patients with and without $\mathrm{HE}$.

\section{DISCUSSION}

This study reveals that the ammonia level used during $\mathrm{HE}$ attacks in patients with chronic liver disease does not have a direct correlation with $\mathrm{HE}$ and mortality. However, it shows that it is associated with mortality in patients with chronic liver disease regardless of the cause of death.

When the predisposing factors causing $\mathrm{HE}$ are examined in our study, infections were found to be the most common precipitating factor. Similarly, in studies conducted in Pakistan and Spain, it has been observed that the most common precipitating factor for $\mathrm{HE}$ is infection $(8,9)$. In the patients included in our study, the most common cause of HE was recorded as urinary tract infection. Other leading infectious reasons were acute gastroenteritis, pneumonia and peritonitis. Other common precipitating causes were kidney failure, heart failure and gastrointestinal bleeding. In a study conducted in Erzurum and Istanbul in our country, the factors causing HE were examined and it was seen that the most common cause was infection. Among the reasons examined, the most frequent ones were peritonitis, gastroenteritis, pneumonia, urinary tract infection, and calculous cholecystitis. Non-infectious causes were kidney failure, gastrointestinal bleeding, heart failure, and constipation, similar to our study $(10,11)$. This can be explained by the weakening of the immune system in patients with liver failure, frequent hospitalizations, and their susceptibility to infections as a result of exposure to catheter procedures.

In our study, the mortality rate in patients with $\mathrm{HE}$ was found to be $25.3 \%$. In a study conducted in our country, the mortality rate was found to be $8 \%$ (11). In another study, the mortality rate in the United States was reported to be around $7-15 \%$ (12). The high mortality rate in our study may be due to the fact that our hospital is in a more dense area with low sociocultural and economic levels. In relation to this, we think that malnutrition, poor living conditions and not paying attention to hygiene rules increase the tendency to infections in our patients and this has an effect on mortality.

In our study, PT, aPTT and INR values were found to be longer than normal in patients with $\mathrm{HE}$ and a statistically significant difference was found between survivors and those who died. In a similar study conducted by Pan C et al in China, the INR value was found to be prolonged in patients with HE (13). In another study conducted in the USA, prolonged PT and INR were found in patients with severe liver failure accompanied by HE (14). Similarly, prolongation of INR has been observed in studies conducted in the USA and HE with liver cirrhosis in Ukraine $(15,16)$. Similarly, in the study conducted by Koch et al, the INR level was found to be longer than normal in cases with HE resulting in death (16). In a study conducted in China, it was found that the high INR value at discharge after HE predicts readmission to the hospital and this may be associated with mortality (17). When the prolongation of aPTT, PT and INR levels among hemostasis parameters is considered in terms of mortality in patients with HE, it emerges as an important parameter. We think that using hemostasis values to predict re-application in follow-up will be an important prognostic approach. In fact, in new studies, a reduction in mortality rate can be achieved with factor treatments. In our study; AST, ALT, GGT and ALP values were statistically significant and increased in HE patients who died. In another study 
conducted in China, it was observed that when the ammonia level increased in patients with HE, the AST elevation was more pronounced (13). Contrary to our study, ALT elevation was found to be more pronounced in a study conducted in the United States (16). This may be due to the fact that they included patients with an INR more than 2.0 and an ALT ten times higher than normal among patients who were eligible for the definition of acute liver injury (new and sudden onset of liver function loss in a person without previous liver disease) without known liver disease (18). Our study includes patients with chronic liver disease who developed HE due to acute failure. In other studies from Ukraine and America, ALT and AST values were found to be increased when blood ammonia level increased $(15,16)$. Studies show that a significant increase in AST and ALT values is expected in $\mathrm{HE}$ patients. The difference between AST and ALT may be due to etiological reasons, regional differences and differences in patient groups. In our study, the total bilirubin and direct bilirubin values of the patients with $\mathrm{HE}$ were found to be higher than the living group. In studies conducted in Ukraine and America, it has been found that total bilirubin and direct bilirubin values increase in $\mathrm{HE}$ patients $(15,16)$. Our study is also in accordance with the literature on this subject. We also found that liver function tests, bilirubin levels, and coagulation tests were significantly higher in all of the patients who died than those who survived.

In studies conducted in Ukraine and America, it has been observed that when the blood ammonia level increases, the platelet value decreases $(15,16)$. In our study, there was a statistically significant difference between $\mathrm{HE}$ patients who died and those who survived. However, there was no statistical difference between all patients. Moderate thrombocytopenia is an expected condition in liver failure (6). Increased liver dysfunction in patients with HE may cause thrombocytopenia to deepen in the HE group patients that die.
Hu et al found that hyperammoniemia was significant in 28-day mortality in acute and chronic liver failure (19). Another study showed that increased ammonia levels are associated with intensive care mortality. This has yielded consistent results in both those with and without liver disease (20). Our study showed that increasing ammonia in HE patients has no effect on mortality, but there is a correlation with the mortality of chronic liver disease. Increasing ammonia weakens immunity, increases hepatocyte damage and impairs liver recovery. This increases liver damage (2). In another study, it was shown that there is a relationship between the death incidence of cirrhosis patients and hyperammoniemia (2). Ammonia is not directly related to the clinical severity of patients with HE. However, infection and inflammation were found to be effective in the severity of HE (21). Our study also supported this showing that high ammonia level does not affect mortality in HE. However, our mortality rate was high and our patients had infection at a rate of $53.27 \%$.

Retrospective study design was the most important reason for limitation. There were etiological differences among the causes of chronic liver disease. We could not reach the records about the treatment approach of the patients. This situation may have prevented us from forming a group with standard treatment. In addition, the most important factor that triggered HE was infection in our study. This may have increased the mortality rate with the association of HE and infection.

In $\mathrm{HE}$, not only blood ammonia levels deteriorate. In addition, changes in AST, ALT, bilirubin values, coagulation tests and platelet levels are observed. Ammonia level does not predict anything in terms of mortality in patients with HE. Liver function tests, bilirubin, coagulation tests and platelet values in HE are more significant than ammonia in terms of mortality. However, these values are also significant in terms of mortality in patients with chronic liver disease. Ammonia level may be valuable in terms of mortality if it increases in chronic liver diseases, but not in HE. 
Conflict of Interest: None.

Support and Acknowledgment: None. Thank Dr. Zübeyir Cebeci to supporting statistical analysis.

Researchers' Contribution Rate Statement: The authors declare that they have contributed equally to the article. Main idea-planning: ABE, İG; analysis-interpretation: ABE, İG; data provision: ABE, İG; writing; ABE, İG; review and correction: $\mathrm{ABE}, \mathrm{I} G$; endorsement: $\mathrm{ABE}$, İ.

Ethics Committe Aproval: Ankara Numune Training and Research Hospital Clinical Research Ethics Committee, date: 28.09.2019, issue number: E-19-2644.

\section{REFERENCES}

1. Wijdicks EF. Hepatic encephalopathy. NEJM. 2016;375(17):1660-70.

2. Shalimar, Sheikh MF, Mookerjee RP, Agarwal B, Acharya SK, Jalan R. Prognostic role of ammonia in patients with cirrhosis. Hepatology. 2019;70(3):98294.

3. Cadranel JF, Lebiez E, Di Martino V, Bernard B, El Koury S, Tourbah A et al. Focal neurological signs in hepatic encephalopathy in cirrhotic patients: an underestimated entity? Am J Gastroenterol. 2001;96(2):515-8.

4. Kantar FU. Approach to elevated liver function tests. Klinik Tıp Bilimleri Dergisi. 2017;5(2):30-8.

5. Kramer L, Tribl B, Gendo A, Zauner C, Schneider $\mathrm{B}$, Ferenci $\mathrm{P}$ et al. Partial pressure of ammonia versus ammonia in hepatic encephalopathy. Hepatology (Baltimore, Md). 2000;31(1):30-4.

6. Özatlı D, Haznedaroğlu İC, Büyükaşık Y, Şimşek H. Anemia in chronic liver disease. Türkiye Tıp Dergisi. 1999;6(4):238-45.

7. Ferenci P, Lockwood A, Mullen K, Tarter R, Weissenborn K, Blei AT. Hepatic encephalopathy definition, nomenclature, diagnosis, and quantification: final report of the working party at the 11th World Congresses of Gastroenterology, Vienna, 1998. Hepatology. 2002;35(3):716-21.

8. Maqsood S, Saleem A, Iqbal A, Butt JA. Precipitating factors of hepatic encephalopathy: experience at Pakistan Institute of Medical Sciences Islamabad. JAMC. 2006;18(4):58-62.

9. Vergara-Gomez M, Flavia-Olivella M, Gil-Prades M, Dalmau-Obrador B, Cordoba-Cardona J. Diagnosis and treatment of hepatic encephalopathy in Spain: results of a survey of hepatologists. Gastroenterol Hepatol. 2006;29(1):1-6.

10. Çadırcı K, Cerrah S. Evaluation of precipitating factors in our patients with hepatic encephalopathy. Firat Med J. 2019;24(2):75-9.

11. Öztürk O, Tuncer İ, Doğanay L, Yorulmaz E, Çolak Y, Enç FY. Factors triggering hepatic encephalopathy in cirrhotic patients. Medeniyet Med J. 2010;25(4):164-8.

12. Saab S. Evaluation of the impact of rehospitalization in the management of hepatic encephalopathy. Int J Gen Med. 2015;5(8):165-73.

13. Pan C, Xu LJ, Zhou R, Zhou W, Huang JR. Multivariate analysis of hepatic encephalopathy occurrence in patients with liver failure. Chinese Journal of Hepatology. 2012;20(6):434-7.

14. Kamath PS, Wiesner RH, Malinchoc M, Kremers W, Therneau TM, Kosberg CL et al. A model to predict survival in patients with end-stage liver disease. Hepatol. 2001;33(2):464-70.

15. Djiambou-Nganjeu H. Hepatic encephalopathy in liver cirrhosis. J Transl Int Med. 2017;5(1):64-7.

16. Koch DG, Speiser JL, Durkalski V, Fontana RJ, Davern T, McGuire B et al. The natural history of severe acute liver injury. Am J Gastroenterol. 2017;112(9):1389-96.

17. Hu X-P, Gao J. International normalized ratio and Model for End-stage Liver Disease score predict short-term outcome in cirrhotic patients after the 
resolution of hepatic encephalopathy. World $\mathrm{J}$ Gastroenterol. 2019;25(26):3426-37.

18. Lee WM, Squires Jr RH, Nyberg SL, Doo E, Hoofnagle JH. Acute liver failure: summary of a workshop. Hepatology. 2008;47(4):1401-15.

19. Hu C, Huang K, Zhao L, Zhang F, Wu Z, Li L. Serum ammonia is a strong prognostic factor for patients with acute-on-chronic liver failure. Sci Rep. 2020;10(1):16970.

20. Li J, Li R, Gao Y, Jin X, Zhang J, Ren J et al. Increasing serum ammonia level is a risk factor for the prognosis of critically ill patients: A multicenter retrospective cohort study. J Crit Care. 2021;62:21822.

21. Shawcross DL, Sharifi Y, Canavan JB, Yeoman $\mathrm{AD}$, Abeles RD, Taylor $\mathrm{NJ}$ et al. Infection and systemic infammation, not ammonia, are associated with Grade 3/4 hepatic encephalopathy, but not mortality in cirrhosis. J Hepatol. 2011;54(4):640-9. 